\title{
A NARRATIVA RACIAL NO PENSAMENTO GEOGRÁFICO: NOTAS PARA UM DEBATE
}

Jonathan da Silva Marcelino ${ }^{1}$

RESUMO: O presente estudo é um esforço na tentativa de circunscrever o debate das relações raciais no interior da ciência geográfica. Produzimos nesse trabalho um diálogo com as principais referências da epistemologia da Geografia. Como forma de operacionalização, nossa análise buscou contemplar um vasto recorte temporal que perpassa desde o conhecimento geográfico elaborado no contexto da Antiguidade Clássica até a Geografia Tradicional e seus principais expoentes na Europa (Humboldt, Ritter, Ratzel e La Blache) e no Brasil (Aroldo de Azevedo e Delgado de Carvalho).

Palavras-chave: Relações Étnico-Raciais, Pensamento Geográfico, Teoria da Geografia.

\section{THE RACIAL NARRATIVE IN GEOGRAPHIC THOUGHT: NOTES FOR A DEBATE}

\begin{abstract}
The present study is an effort in an attempt to circumscribe the debate on race relations within geographic science. In this work, we produced a dialogue with the main references of the epistemology of Geography. As a way of operationalization, our analysis sought to contemplate a vast time frame that runs from the geographic knowledge elaborated in the context of Classical Antiquity to Traditional Geography and its main exponents in Europe (Humboldt, Ritter, Ratzel and La Blache) and in Brazil (Aroldo Azevedo and Delgado de Carvalho).

Keywords: Ethnic-Racial Relations, Geographic Thought, and Theory of Geography.

\section{LA NARRATION RACIALE DANS LA PENSÉE GÉOGRAPHIQUE: NOTES POUR UN DÉBAT}

RÉSUMÉ: La présente étude est un effort pour tenter de circonscrire le débat sur les relations raciales dans la science géographique. Dans cet ouvrage, nous avons produit un dialogue avec les principales références de l'épistémologie de la géographie. Comme moyen d'opérationnalisation, notre analyse a cherché à contempler un vaste laps de temps qui va des connaissances géographiques élaborées dans le contexte de l'Antiquité classique à la géographie traditionnelle et ses principaux représentants en Europe (Humboldt, Ritter, Ratzel et La Blache) et au Brésil (Aroldo Azevedo et Delgado de

\footnotetext{
${ }^{1}$ Geógrafo, Mestre e Doutor em Geografia Humana/USP. Professor do Ensino Fundamental II \& Médio da Secretaria Municipal de Educação de São Paulo - SME/SP. E-mail: prof.jonathan@uol.com.br
} 
Carvalho).

Mots-clés: Relations Ethnico-Raciales, Pensée Géographique, et théorie de la Géographie.

\section{CONSIDERAÇÕES INICIAIS}

Atualmente muitos geógrafos (SANTOS, 2007, 2010, 2011; RATTS, 2003; 2004; 2010; PORTO-GONÇALVES, 2006) que reconhecem a questão étnico-racial como um elemento central e estruturante no processo de compreensão da formação da sociedade brasileira no processo de enfrentamento das desigualdades sociespaciais estão reproduzindo o percurso teórico do debate das relações étnico-raciais no interior da ciência na tentativa de estabelecer um elo que possibilite essa temática se consagrar como um dos temas possíveis de serem abordados pela ciência geográfica contemporânea.

É nesse movimento que este trabalho se insere. Acreditamos que as categorias de raça, racismo e relações raciais estão dentro do escopo teórico da Geografia, sobretudo porque são categoriais que estão ancoradas em leituras espaciais. Ou seja, enquanto dimensões do social, as categorias de raça, racismo e relações raciais se dão no espaço, com o espaço e a partir do espaço - ou seja, o espaço também é uma dimensão constitutiva delas (SANTOS, 2007).

Segundo Malachias (2006) a compreensão da questão das relações raciais no Brasil perpassa necessariamente pela compreensão do modelo cívico, do modelo cultural e do modelo político brasileiro, portanto pela compreensão dos sistemas de ideias interpretativas fundadoras e formadoras da civilidade brasileira.

De modo que em uma sociedade marcada pelo racismo enquanto sistema de dominação e exploração, que organiza e estrutura relações de poder é na vivência e na experiência de indivíduos e grupos que as relações raciais vão se consubstanciar. Isso nos permite refletir sobre como indivíduos e grupos constituem experiências das relações raciais no, com e a partir do espaço. Leituras 
de espaço estão, portanto, na base de conformação do nosso padrão de relações raciais:

[...] primeiro, porque leituras de espaço orientam a própria constituição e naturalização da ideia de 'raça' e as classificações em grupos raciais; segundo, porque são leituras de espaço que estruturam e autorizam as hierarquizações entre os grupos raciais" (SANTOS, 2007, p. 43).

A "raça", portanto, é uma produção social antiga na história da humanidade e apresenta múltiplos conteúdos que vão, em contínuo, da ciência (aspectos biologizantes) até a ideologia (aspecto etno-semântico e político), sempre que está em jogo a diversidade da espécie Homo sapiens2 (GUIMARÃES 1999; SEYFERTH, 1995). Como toda construção histórico social, a raça apresenta características plásticas e já adquiriu diferentes acepções ao longo da história. Seu significado vai variar no tempo e no espaço de acordo com a vontade e os interesses dos grupos sociais hegemônicos que se utilizavam (e alguns desses ainda nos dias de hoje utilizam) desses repertórios por razões e interesses inúmeros, alguns, inclusive, de dominação.

Nesse bojo, para contemplar com êxito o desafio de circunscrever o debate das relações raciais dentro de uma perspectiva geográfica faremos na primeira parte do texto, um exercício de digressão histórica e imersão no pensamento geográfico3 para traçar um panorama do percurso teórico trilhado pelas

\footnotetext{
${ }^{2} \mathrm{Na}$ história da ciência, a classificação racial dos seres vivos começa na Zoologia e na Botânica. Era importante encontrar categorias maiores por sua vez subdivididas em categorias menores e subcategorias, e assim por diante. Os termos para designar as categorias são como todos os fenômenos linguísticos convencionais e arbitrários. Assim, as principais categorias foram as divisões filo e subfilo, a classe, a ordem e a espécie. Como homens, pertencemos ao filo dos cordados, ao subfilo dos vertebrados (como os peixes), à classe dos mamíferos (como as baleias), à ordem dos primatas (como os grandes símios) e à espécie humana (homo sapiens) como todos os homens e todas as mulheres que habitam nossa galáxia. Somos espécie humana porque formamos um conjunto de seres, homens e mulheres capazes de constituir casais fecundos, isto é, capazes de procriar, de gerar outros machos e outras fêmeas. Sem a classificação, não é possível falar de milhões de espécies de animais do universo conhecido. Apenas, no seio da espécie homo sapiens (homo sábio), a que pertencemos, somos hoje cerca de 6 bilhões de indivíduos (MUNANGA 2003, p. 14).

3 Nas palavras do geógrafo Antônio Carlos Robert Moraes (1991, p. 32) "Por pensamento geográfico entende-se um conjunto de discursos a respeito do espaço que substantivam as
} 
categorias de raça, racismo e relações raciais no âmbito da Geografia. Primeiramente, analisaremos a repercussão dessas questões no contexto do conhecimento geográfico elaborado na Antiguidade clássica e posteriormente no bojo da Geografia Moderna/tradicional.

Partimos do pressuposto de que o saber geográfico (muito antes de adquirir o status de ciência) já operava dentro de uma perspectiva raciológica. Essa tendência adquiriu contornos mais complexos quando a Geografia foi promovida a condição de disciplina acadêmica no século XIX. Vale lembrar que as categorias de raça e racismo tão preciosa ao debate da Relações Étnico-Raciais possuem uma vasta tradição espacial que dialoga com a identidade epsitêmica da Geografia.

Na segunda parte do texto, temos como objetivo promover uma reflexão sobre repercussão e os desdobramentos da temática racial no interior da geografia brasileira, nos interessa a presença constante dessa temática nos estudos produzidos pelos pioneiros Delgado de Carvalho, e Aroldo de Azevedo, dois geógrafos com uma produção literária de grande projeção e prestígio no Brasil.

\section{A GÊNESE DO SABER GEOGRÁFICO E SUA PERSPECTIVA RACIOLÓGICA}

A geografia ${ }^{4}$ é um saber quase tão antigo quanto à própria história da

concepções que uma dada sociedade, num momento determinado, possui acerca do seu meio (desde o local ao planetário) e das relações com ele estabelecidas. Trata-se de um acervo histórico e socialmente produzido, uma fatia da substância da formação cultural de um povo. Nesse entendimento, os temas geográficos distribuem-se pelos variados quadrantes do universo da cultura. Eles emergem em diferentes contextos discursivos, na imprensa, na literatura, no pensamento político, na ensaística, na pesquisa científica etc. Em meio a estas múltiplas manifestações vão sedimentando-se certas visões, difundindo-se certos valores. Enfim, vai sendo gestado um senso comum a respeito do espaço. Uma mentalidade acerca de seus temas. Um horizonte espacial, coletivo".

${ }^{4}$ A geografia como forma de conhecimento é um saber produzido de longa data. Em alguns trabalhos sobre a história da geografia, a exemplo de Capel \& Urteaga (19984), Andrade (I 987), Sodré (1989) e Moraes (1989 e 1990), é possível detectar o quão remoto é a origem desse saber, tendo em vista que os primeiros indícios de uma preocupação com a distribuição espacial dos 
humanidade. Desde a Antiguidade clássica ${ }^{5}$ já se produzia conhecimento geográfico, porém ainda não sistematizado. Tratava-se de um conhecimento disperso e que ainda não era reconhecido com o nome de geografia. Esse saber se desenvolveu inicialmente como um conhecimento prático para resolver problemas imediatos do cotidiano. Designava-se como saber geográfico, na Antiguidade clássica, os relatos de viagem, as noções e os escritos sobre os variados lugares, as ideias e as experiências acerca dos fenômenos naturais e os diferentes tipos de conhecimento espacial que estavam dispersos, misturados, ou, ainda, subordinados a outros campos de conhecimentos. Não havia uma ciência geográfica sistematizada.

Havia filósofos, historiadores, astrônomos, cientistas e outros que se denominavam de geógrafos ou eram socialmente reconhecidos como tal, por tratar de questões de cunho geográfico, e não da construção de uma ciência geográfica.

De modo que é nesse contexto intelectual que podemos detectar já na Grécia Antiga os primeiros indícios da inserção temática da ideia de raça no conhecimento geográfico. Muito antes mesmo de a Geografia se constituir enquanto disciplina acadêmica autônoma, os geógrafos gregos já formulavam explicações para justificar as causas da diversidade na composição da

\footnotetext{
fenômenos naturais e sociais surgiram desde os primórdios da humanidade. O saber espacial possui sua gênese na Antiguidade Clássica quando se designava como "geografia" ou "saber geográfico" os relatos de viagem, as noções e os escritos sobre os variados lugares, as ideias e as experiências acerca dos fenômenos naturais etc. Nas palavras de Nelson Werneck Sodré (1984) esse período pode ser denominado como "pré-história da Geografia". É por essa razão que nesse tópico do trabalho utilizaremos a palavra "geografia" na grafía minúscula como forma de designar esse período de produção de um conhecimento que era indispensável para a vida cotidiana. A utilização da grafía minúscula também é uma forma de distinguir esse conhecimento de uma Geografia acadêmica e institucionalizada que data do final do século XIX.

${ }^{5} \mathrm{O}$ termo Antiguidade Clássica refere-se a um longo período da História cultural que se estende aproximadamente entre o século VIII a.C. e o século V d.C. Este período é centrado no mar Mediterrâneo, compreendendo as civilizações entrelaçadas da Grécia antiga e da Roma antiga conhecidas como o mundo greco-romano. Foi nesse momento histórico que a sociedade grega e romana floresceu e exerceu grande influência em toda a Europa, norte de África e Ásia ocidental .
} 
humanidade. A busca pela raça (génos ${ }^{6}$ ) como chave explicativa, quase sempre fazia referência à ordenação hierárquica dos diferentes povos e grupos culturais. Segundo o cientista social Carlos Moore Wedderburn (2007, p.45).

[...] É possível rastrear a evolução da visão raciológica dos gregos, ao longo desse período, evidentes nos textos produzidos pelas suas elites dominantes. Isso porque, antes de entrar numa relação de conflito e dominação com o mundo africano, representado no primeiro momento pelas grandes potências que foram Egito e Cartago, tanto gregos quanto romanos formularam uma precoce visão racializada. Esta se robusteceu à medida que a influência imperial da Grécia, e depois de Roma, se estendeu pelo Oriente Médio e pela África do Norte. No que concerne às bases do pensamento helenístico e romano sobre a natureza humana, o texto da llíada, de Homero, registra enigmáticas referências a lutas violentas pela posse do Mediterrâneo, entre 'xantus' (cor clara) e 'melantus' (cor preta), que supostamente se referem aos autóctones (pelasgos) e aos invasores arianos (aquéos e dórios). Com toda probabilidade, trata-se de uma simbologização (transformação em mitologias e fantasmas) de confrontações reais entre povos europeus autóctones e sedentários de pele negra, por uma parte, e de invasores ariano-europeus nômades provindos dum berço frio euro-asiático.

Um dos muitos exemplos que sintetiza essa perspectiva raciológica empreendida pelos gregos na tentativa de sujeição do outro através da hierarquização de características geográficas, culturais, e fenotípicas pode ser constatado no processo de criação e fortalecimento da categoria de "bárbaro" criado pelos geógrafos gregos durante o período compreendido entre o sexto e o

\footnotetext{
${ }^{6}$ Compreendemos a ideia de "génos" na Grécia Antiga como agrupamento familiar primitivo que se constituía a partir de um clã patriarcal, do qual praticamente todos os membros descendiam de um antepassado comum. Cada génos tinha seu próprio deus, seus ritos específicos, suas regras de conduta social, seus cultos e festividades eram celebrados apenas no seio da família e somente por seus membros, que perpetuavam o sangue do antepassado. Nessa "sociedade gentílical", tudo que era produzido e cultivado era também propriedade comum de todo o grupo. Em nosso entendimento, a sociedade gentílical pode ser definida como regime da gens cujos membros, unidos por cerimônias sagradas ajudavam-se em todas as necessidades da vida e na qual o vínculo de nascimento garantia o nome dos antepassados, estando os parentes ligados uns aos outros por deveres de solidariedade, tendo a terra como propriedade coletiva (MELO, 2009, p. 26)
} 
quinto século a.C. no contexto das guerras médicas7 contra os persas. O termo "bárbaro", até então utilizado para indicar os povos que não falavam a língua grega, passou a significar, em termos assimétricos, o outro, a antítese, o diferente, o estranho, o retrato distorcido, ou seja, o "não grego". Tal como podemos constatar nos estudos de François Hartog, citado a partir do trabalho de Wedderburn;

É entre o sexto e o quinto século a.C. que "bárbaro", no sentido de não grego, forma, associado a "grego", um conceito antônimo e assimétrico, acoplando um nome próprio, Héllenes, e uma designação genérica, bárbaroi. As Guerras Médicas desempenharam, seguramente, um papel catalisador. O campo da alteridade passou a ficar distribuído por muito tempo em torno dessa nova polaridade. Os gregos, de um lado, e do outro, todos os outros, reunidos pelo simples fato de não serem gregos. Não é preciso dizer que essa classificação binária e fortemente assimétrica, concebida por gregos e para eles, não pode ser manejada senão por eles e só para eles é operatória. Mas, antes de tornar-se ulteriormente uma expressão feita, em que os romanos terão dificuldade de encontrar um lugar, não há dúvida que as guerras médicas Ihe deram uma significação precisa, dotando o antônimo de um rosto: o do persa. O bárbaro é, antes de tudo, mais que todos e por muito tempo, o persa. $\mathrm{E}$ o bárbaro por excelência será o grande Rei, encarnação da hýbris despótica. Assim é Xerxes, que na sua desrazão, creu poder lançar cadeias sobre o Helesponto. As guerras contra os persas vão, além disso, conduzir a uma territorialização do bárbaro, cujo domínio é a Ásia, a qual ele reivindica (ou se diz que reivindica) como sua [...]. Daí em diante, a oposição entre Europa e Ásia, figurada pela imagem das duas irmãs inimigas, irá se sobrepor quase que exatamente ao binômio grego/bárbaro (WEDDERBURN, 2007, p.42).

\footnotetext{
7 Guerras Médicas, Guerras Greco-Persas, Guerras Persas ou Guerras Medas são designações dadas aos conflitos bélicos entre os antigos gregos e o Império Aquemênida durante o século $\mathrm{V}$ a.C. Ocorreu entre os povos gregos (aqueus, jônios, dórios e eólios) e os medo-persas, pela disputa sobre a Jônia na Ásia Menor, quando as colônias gregas da região, principalmente Mileto, tentaram livrar-se do domínio persa. A causa da guerra se deveu ao fato de que os persas estavam expandindo o seu território e conquistando colônias gregas para assim dominar o comércio do Mar Egeu. Os gregos não aceitavam essa hegemonia e entraram na disputa pelas terras da Ásia Menor.
} 
Na geografia praticada na antiguidade, o termo bárbaro, servia como um par assimétrico do grego e ilustrava o surgimento de uma visão política da partilha do mundo entre gregos e bárbaros, ou seja, não significava necessariamente crueldade, desconhecimento, falta de caráter, enfim, a barbárie, nesse contexto, diz respeito a uma clivagem geográfica e política com fortes indícios étnicos.

Nos textos ficcionais, os geógrafos gregos já se referiam a uma mítica "cidade dos escravos" (Doulopolis ou doulôn polis) que supostamente estaria situado em lugares como Egito, Síria, Líbia, Arábia e também em Creta. Segundo Wedderburn (Ibidem, p. 43), “A cidade de escravos, era também mencionada como cidade dos malvados (Ponêropolis) ou cidade de bárbaros". Através dessa narrativa mítica, fica evidente que, na visão raciológica produzida pela Geografia da Antiguidade grega, a territorialidade do bárbaro quase sempre estava associada às regiões da Ásia, do norte e do noroeste africano, e que em geral eram (e continuam sendo) regiões historicamente ocupadas por povos melanodérmicos ${ }^{8}$.

Para os geógrafos gregos, alguns homens eram escravos por natureza e, ainda que fossem libertos e conquistassem a liberdade, pouco a pouco voltariam à condição escrava, pois nasceram com espírito servil e nada seria capaz de curálos. Essas reflexões são encontradas na obra $A$ Política do filósofo e geógrafo grego Aristóteles ${ }^{9}$. Segundo ele, a antítese superior-inferior é encontrada em todos os lugares na natureza,

[...] como entre a alma e o corpo, o intelecto e o apetite, entre o homem e o animal, o homem e a mulher, e se tal diferença existe,

\footnotetext{
${ }^{8}$ Grupos humanos que apresentam a presença de melanina acentuada na epiderme.

${ }^{9}$ Aristóteles introduz a distinção entre escravo por lei e por natureza. Em suas palavras, "é naturalmente escravo aquele que tem tão pouca alma e poucos meios que resolve depender de outrem. Tais são os que só têm instinto, vale dizer, que percebem muito bem a razão nos outros, mas que não fazem por si mesmos uso dela [...]Para eles, é melhor servirem do que serem entregues a si mesmos" (ARISTÓTELES 2002, p. 15). Para o geógrafo-filósofo, além da servidão natural, existe aquele sistema de servidão estabelecido pela lei, "esta lei é uma espécie de convenção geral, segundo a qual a presa tomada na guerra pertence ao vencedor" (Ibidem, p 16).
} 
é para vantagem de ambos que um deve mandar no outro. [...] A natureza tende a produzir tal distinção entre os homens, fazendo de uns fortes para o trabalho e de outros aptos para a vida política (ARISTÓTELES, 2002, p.32).

O autor acrescenta que

A natureza, por assim dizer, imprimiu a liberdade e a servidão até nos hábitos corporais. Vemos corpos robustos talhados especialmente para carregar fardos e outros usos igualmente necessários; outros, pelo contrário, mais disciplinados, mas também mais esguios e incapazes de tais trabalhos, são bons apenas para a vida política, isto é, para os exercícios da paz e da guerra (Ibidem, p. 14).

Logo, para Aristóteles, e boa parte dos seus contemporâneos, alguns homens são livres por natureza, e outros, escravos.

Não é apenas necessário, mas também vantajoso que haja mando por um lado e obediência por outro; e todos os seres, desde o primeiro instante do nascimento, são, por assim dizer, marcados pela natureza, uns para comandar, outros para obedecer. [...] Aquele que manda e aquele que obedece são de espécies diferentes (Ibidem, p. 12).

Fica explícito, na defesa política expressada por Aristóteles, que a legitimidade do processo de escravidão se atribui ao fato de ela se dirigir especialmente aos bárbaros, e não aos gregos, tendo em vista que os bárbaros seriam supostamente mais suscetíveis à escravidão.

Ainda nas palavras de Aristóteles, “os bárbaros são virtualmente escravos, seus próprios modos de vida admitem uma servidão da qual são 'incapazes' de se desfazer, malgrado sua reconhecida reputação intelectual". (Ibidem, p. 17). Nesse sentido, por mais sábios que fossem os egípcios, eles seriam 'politicamente' inferiores" (WEDDERBURN 2007, p. 65), e, quanto aos gregos, esses seriam supostamente descendentes dos deuses, e por isso, sob nenhuma circunstância, 
deveriam escravizar uns aos outros. Segundo a obra de Carlos Moore Wedderburn (2007, p. 45).

É sempre da escravidão do outro que se fala ao tocar no assunto. A natureza escrava é dada pelo corpo e o habitat dos outros povos, assim como a liberdade grega é uma garantia do clima e, por conseguinte, de sua raça (génos). Determinismo biológico e determinismo geográfico convergem para o estatuto negativo do estrangeiro.

É sempre da escravidão do outro que se fala ao tocar no assunto. A natureza escrava é dada pelo corpo e o habitat dos outros povos, assim como a liberdade grega é uma garantia do clima e, por conseguinte, de sua raça (génos). Determinismo biológico e determinismo geográfico convergem para o estatuto negativo do estrangeiro.

Necessitavam de um tirano que os subjugasse, o que supostamente era muito diferente dos gregos que, sob nenhuma circunstância, aceitariam tais condições.

Para Aristóteles, existe uma convergência direta entre as características ambientais e geográficas e as características morais e físicas que, segundo ele, justificavam a superioridade grega, e a inferiorização e escravização de outros grupos e povos. Ele ousa afirmar que;

As nações situadas nas regiões frias - e, particularmente, as europeias - são cheias de coragem, mas têm falta, sobretudo, de inteligência e habilidade técnica; é por isso que, vivendo em nações relativamente livres, são incapazes para organização política e impotentes para exercer a supremacia sobre seus vizinhos. Ao contrário, as nações asiáticas são inteligentes e de espírito inventivo, mas não têm nenhuma coragem - e é por isso que vivem numa sujeição e escravidão contínuas. Mas a raça dos gregos, que ocupa uma posição geográfica intermediária (meseíei), participa de maneira semelhante das qualidades dos dois grupos de nações, pois é corajosa e inteligente - e essa é a razão pela qual leva uma existência livre sob excelentes instituições políticas, sendo mesmo capaz de governar o mundo 
inteiro, sem lograr ter uma única constituição (apud WEDDERBURN, 2007, p. 69).

Em outro texto, no livro VI de Fisonomia, Aristóteles reafirma suas ideias e acrescenta que

Aqueles que são muito negros são covardes, como, por exemplo, os egípcios e os etíopes. Mas os excessivamente brancos também são covardes, como podemos ver pelo exemplo das mulheres; a coloração da coragem está entre o negro e o branco (UNESCO, 2010, p. 103).

A maioria dos geógrafos da antiguidade clássica compartilhavam do mesmo modelo de interpretação de Aristóteles. Na perspectiva desses pensadores:

Se os asiáticos são hesitantes, sem coragem e de caráter menos belicoso e mais doce do que os europeus, é preciso procurar a causa essencial disso na natureza das estações. Sem sofrer grandes variações, elas são, entre aqueles, quase todas idênticas, passando insensivelmente do calor ao frio. Nessas condições de temperatura, a alma não experimenta essas vivas emoções, como o corpo não se ressente dessas bruscas mudanças, umas e outras conferindo, evidentemente, ao homem um caráter mais rude, mais rebelde, mais violento do que quando ele vive nas condições de temperatura invariável; porque essas passagens bruscas de um extremo a outro despertam o espírito do homem e arrancam-no ao estado de preguiça e de insatisfação (SODRÉ, 1984, p. 37).

Podemos detectar essas mesmas representações no texto Epínomis, tratado atribuído ao filósofo Platão, mentor de Aristóteles. Nas palavras do filósofo;

Todo grego, deve considerar que temos, na Grécia, um clima que é, entre todos, o mais favorável, a excelência, pois está colocado no meio (mésos) entre o frio e o quente. Sugere, pois, que, 'tudo o que os gregos recebem dos bárbaros, embelezam e levam à perfeição (télos) Assim, mesmo que povos bárbaros fossem pioneiros em certas áreas do conhecimento, seus saberes seriam sempre virtualmente inferiores em relação àqueles que os gregos 
fossem capazes de desenvolver em seu lugar (apud WEDDERBURN 2007, p. 69).

A partir dessas reflexões, podemos afirmar que os gregos elaboraram uma Geografia raciológica que considerava como indissociável as categorias “estrangeiro-escravidão-inferioridade". Para o sociólogo Wedderburn (2007), eram basicamente três formulações gerais que orientavam as proposições da geografia grega em relação a outros grupos.

$\left.1^{\circ}\right)$ a continuidade entre características físicas e mentais;

$2^{\circ}$ ) a relação entre traços mentais, físicos e morais do grupo é inalterável pela vontade humana;

$3^{\circ}$ ) as características humanas são determinadas por fatores hereditários ou influências externas como clima ou a geografia.

Todas essas formulações estavam diretamente articuladas na produção do conhecimento geográfico da antiguidade clássica, em especial, o ponto terceiro põe em evidência de forma definitiva a associação entre o conhecimento geográfico e o trato da questão raciológica. Desde a Antiguidade, essas questões perpassam diretamente o campo de reflexões da geografia, o que reafirma nossa tese de que o debate sobre raça e relações raciais é evidentemente um debate geográfico.

Estamos falando de raça não como um conceito biológico, mas, enquanto conceito social, enquanto constructo social, que é princípio ordenador de relações sociais (SANTOS, 2007). De modo que, para os geógrafos gregos da Antiguidade, existia uma relação indissociável entre a ideia de raça e a origem territorial dos diferentes grupos e povos.

A raça, portanto, seria nesse contexto uma categoria eminentemente geográfica, uma vez que ela serviria como marcador de evidência da origem territorial. Uma noção que, para nós, até os dias atuais, está firmemente assentada sobre associações de leituras espaciais e identidades geoculturais. “Ou 
seja, há um conjunto de associações artificiais que sustentam comportamentos baseados nesta associação de grupos raciais a regiões do planeta - tentando, de certa forma, "naturalizar" - o constructo de 'raça"' (SANTOS, 2007, p. 21).

Afinal, quando falamos em "negros", remetemos diretamente à ideia de uma comunalidade, se não biológica, certamente de origem histórico-geográfica: África. De igual modo, quando falamos em "brancos", o mesmo se repete, com a ideia de uma origem que remete à Europa. O mesmo ocorre para como os "índios", associados à América; e os "amarelos", associados à Ásia. Esses referenciais são fruto de representações sociais e espaciais distorcidas uma vez que historicamente homens e mulheres com essas características ocuparam diferentes regiões no planeta.

\section{A PRODUÇÃO DA GEOGRAFIA MODERNA/COLONIAL \& AS INSCRIÇÕES DE RACIALIDADE}

Nos anos seguintes (XVIII- XIX) a expansão do sistema capitalista e o desenvolvimento comercial e industrial do início do século XIX contribuíram para que a Geografia se tornasse uma ciência autônoma. Nesse período, a maior parte do planeta Terra estava conhecida. A Europa articulava um espaço de relações econômicas mundializado; o colonizador europeu possuía informações dos lugares mais variados da superfície terrestre. As representações do Globo estavam desenvolvidas e difundidas pelo uso cada vez maior de mapas. A fé na razão humana, colocada pela Filosofia, abria a possibilidade de uma explicação racional para qualquer fenômeno da realidade. As ciências naturais haviam constituído um conjunto de conceitos e teorias, do qual a Geografia lançaria mão, para formular seu método. E, principalmente, os temas geográficos estavam legitimados como questões relevantes, sobre as quais cabia dirigir indagações científicas (MORAES, 1987, p. 40-41).

É a partir desse contexto que a Geografia se consolidou e foi introduzida 
como disciplina acadêmica nas universidades da Alemanha. Isso posteriormente também ocorreu em outros países da Europa, por exemplo, na França. É na Alemanha, portanto, que aparecem os primeiros institutos e as primeiras cátedras dedicadas à disciplina geográfica; é de lá que vêm as primeiras propostas metodológicas. Enfim, é lá que se formam as primeiras correntes de pensamento na Geografia (Ibidem, p. 42).

Os autores considerados como os pais da ciência geográfica são os geógrafos prussianos Alexandre Von Humbolt (1769-1859) e Karl Ritter (17791859), que difundiram a Geografia na Alemanha. Com a contribuição desses intelectuais, a Geografia estabeleceu suas bases científicas. A partir de Humboldt e Ritter, ficou estabelecida a primeira metodologia da geografia, descritiva, empírica, indutiva e de síntese. A influência de ambos foi decisiva para conferir à Geografia o seu verdadeiro caráter científico. Segundo Moraes (1987, p. 48-49) a obra destes dois autores compõe a base da Geografia moderna (Tradicional). Todos os trabalhos posteriores de Geografia vão se remeter às formulações de Humboldt e Ritter:

Humboldt e Ritter são, sem dúvida, os pensadores que dão o impulso inicial à sistematização geográfica, são eles que fornecem os primeiros delineamentos claros do domínio dessa disciplina em sua acepção moderna, que elaboram as primeiras tentativas de lhe definir o objeto, que realizam as primeiras padronizações conceituais [...] (MORAES, 1987, p. 15).

A Geografia de Ritter é regional e antropocêntrica, enquanto a de Humboldt busca abarcar todo o Globo sem privilegiar o homem. Estes autores criaram uma linha de continuidade no pensamento geográfico, até então inexistente. Além disso, há de se ressaltar o papel institucional, desempenhado por eles, na formação das cátedras dessa disciplina, dando à Geografia uma cidadania acadêmica. 
Assim como no conhecimento geográfico que era produzido pelos gregos na Antiguidade clássica, a Geografia moderna (Tradicional) sistematizada pelos alemães também apresentava elementos de inscrições de racialidade no seu repertório. Dentre eles, podemos destacar as contribuições de Humboldt, que, em seu caráter naturalista, desenvolveu importantes considerações acerca das práticas de racismo e etnocentrismo criado por europeus em relação a outros povos e grupos étnicos. Nesse sentido, Humboldt afirma que

[...] ao sustentar a unidade da espécie humana quero também rechaçar a desagradável pretensão de que existem raças superiores e inferiores. Certamente que as raças são modificáveis, e que há umas mais adequadas que outras por ter conseguido uma maior cultura mental, porém não há raças mais nobres do que outras. E acrescenta ainda: A história não reconhece povos originários ou um berço fundamental da civilização (1848, p. 342 apud ALVES 2005, p. 70).

Mesmo sustentando a existência de uma unidade natural da espécie humana, Humboldt não descartava a possibilidade de que os grupos humanos apresentassem estágios de desenvolvimento distintos; entretanto isso só poderia ocorrer no nível da dimensão cultural. Para o autor, também existia uma conexão direta entre os fatores físicos e biológicos e o progresso e o desenvolvimento de cada sociedade "as condições naturais do espaço terrestre" são fatores imprescindíveis para o progresso humano. Ele apontava que "todo acidente do solo imprime um traço particular ao estado social do povo que habita" (Ibidem, p. 70).

Humboldt também destacava o papel fundamental do que ele considerava como "raças empreendedoras" que não seriam apenas aquelas de lugares mais desenvolvidos, mas todos os grupos humanos que, de algum modo, conseguem sobreviver e avançar mesmo diante dos obstáculos da natureza, independentemente do hemisfério no qual estejam habitando. 
Outro ponto que merece destaque na obra do geógrafo naturalista em relação ao debate racial é seu posicionamento crítico diante da manutenção da prática da escravidão na América e o seu consentimento e apoio pela Igreja católica e pela ampla maioria dos religiosos. Sendo assim, referindo-se ao regime de encomendas dos índios americanos sustentados pelos conquistadores e padres espanhóis, escreveu as seguintes palavras: "A religião, ao que por seus princípios devia favorecer a liberdade, se viu envelhecida desde que se interessou pela escravização do povo" (ALVES 2005, p. 68). Em outra ocasião, em uma passagem de sua obra Viagem as Regiões Equatoriais do Novo Continente, ele se indigna ao perceber o tratamento direcionado aos escravizados. O geógrafo assinala que "É coisa de chorar quando penso que há ainda nas Antilhas colonos europeus capazes de marcar seus escravos com ferro quente para reconhecê-los e identificá-los quando escaparem" (Ibidem, p. 71).

Karl Ritter, por sua vez, também traz grandes considerações à Geografia. Sobretudo quando define o conceito de "sistema natural", isto é, uma área delimitada dotada de uma individualidade. Para ele, a Geografia deveria estudar esses arranjos individuais, e compará-los. "Cada arranjo abarcaria um conjunto de elementos, representando uma totalidade, onde o homem seria o principal elemento" (MORAES, 1986, p. 49).

Assim, a geografia de Ritter é, principalmente, um estudo dos lugares, uma busca de suas individualidades. Toda essa proposta era assentada numa perspectiva religiosa. Para Ritter, a ciência era uma forma de relação entre o homem e o "criador", uma tentativa de aprimoramento das ações humanas, uma aproximação à divindade.

[...] era uma forma de relação entre o homem e o "criador" (com uma dimensão interior de revelação), uma tentativa de aprimoramento das ações humanas, assim uma aproximação à divindade. Neste sentido, caberia à Geografia explicar a individualidade dos sistemas naturais, pois nesta se expressaria 
o desígnio da divindade ao criar aquele lugar específico (MORAES, 1986, p. 49).

Ele acreditava que a ciência racional tinha sido desenvolvida pela providência divina. Segundo o autor, a razão era uma condição do homem se reconciliar com a natureza. O homem entraria em contato com Deus pela contemplação da natureza (LEITÃO, 2017, p. 17). Ritter propôs um sentido para a relação homem-natureza. Para ele, o que o geógrafo procura compreender é a natureza transformada pelo homem e, mais do que isso, o homem transformado pela natureza.

Para Ritter, as adversidades da natureza moldam o caráter e o espírito de um povo, da mesma maneira que o homem é capaz de alterar a natureza. É nessa relação, que é por essência conflituosa, que são moldadas as regiões em suas particularidades. As regiões, a natureza e os homens são, portanto, portadores de história. É a partir da história que o geógrafo se torna capaz de compreender os meandros da relação homem-natureza. Essa busca por sentido mostrou-se necessária frente à diversidade de culturas que os povos europeus se depararam a partir das Navegações na Idade Moderna.

A diversidade cultural era uma pedra no sapato da Europa Iluminada, que queria explicar o mundo por leis gerais. O homem apresentava o mesmo funcionamento biológico em todas as partes do mundo. E o comportamento social podia ser completamente diferente dependendo da cultura (Ibidem, p. 23).

Ainda que Ritter tivesse uma visão eurocêntrica para a História - acreditava que as condições geográficas do continente explicavam por que os povos europeus estavam na frente na corrida do desenvolvimento -, como geógrafo do século XIX ele tentou compreender a forma como as mais diversas culturas se relacionavam com o meio no qual estavam inseridas, e de que forma o meio interferia na formação cultural de um povo. A natureza não seria o reflexo do homem, sendo este uma das partes que compõem a natureza. 
Ainda no século XIX, em suas últimas décadas, por inspirações anteriores, institui-se, dentro da ciência geográfica, a escola "determinista10", que tinha supostamente em Friedrich Ratzel (1844-1904) seu principal expoente. Os princípios dessa escola estão, sobretudo, ligados à relação entre o clima e o homem. Às variações de cultura, de instituições políticas, de formações sociais que aquele determina sobre esse. O determinismo considera o homem um produto do meio vivido, admitindo, portanto, que a preponderância de alguns povos e/ou civilizações sobre outros advém dos fatores naturais, principalmente os climáticos em suas manifestações específicas. Segundo as palavras do próprio Ratzel,

[...] para compreender a humanidade é necessário estudá-la em relação com a Terra, não porque esta sofra caso por caso a influência das inumeráveis condições naturais, mas sim porque constitui parte importante desta Terra, sobre a qual e com a qual foi criada. [...] A humanidade é uma parte da Terra; toda a história anterior do planeta não é nada mais que a preparação para o advento desta que é a maior das evoluções telúricas, e a partir dela toda a história da Terra estará estreitamente ligada à história da humanidade (RATZEL apud MORAES 1987, p. 40).

Um dos pontos que se destaca na obra ratzeliana é o fato de serem atribuídos a ela os primeiros estudos sobre a Geografia humana, dando relevo à ação do homem sobre o espaço, o que até então não se apresentava como preocupação para a disciplina recém-criada. Desse modo, ele valoriza questões históricas e espaciais, de onde surge o seu interesse "pelo movimento dos homens na superfície terrestre e de sua afirmação de que a Geografia deveria se voltar

\footnotetext{
${ }^{10} \mathrm{Na}$ literatura especializada no pensamento geográfico, Ratzel é frequentemente rotulado como "pai" do determinismo ambiental e do imperialismo bismarckiano. Essa leitura equivocada do trabalho produzido por Ratzel em geral, serve apenas para preservar "uma imagem caricaturesca e simplificada do pensamento de Ratzel que pode ser encontrada na maioria dos livros introdutórios à geografia no Brasil. Ratzel = determinismo ambiental. Ponto final. Ratzel tem sido retratado como cientista com uma visão naturalista que reduziu o homem a um animal, ao não diferenciar as suas qualidades especificas; assim, propunha o método geográfico como análogo às demais ciências da natureza; e concebia a causalidade dos fenômenos humanos como idêntica a dos naturais" (SEEMAN 2012, p. 3).
} 
para o estudo da distribuição da população e das regiões do ecúmeno" (LENCIONI, 1999, p. 82). O geógrafo alemão conservou o princípio da Geografia como ciência empírica, mas foi além da descrição, pura e simples, buscando inter-relações entre os vários elementos que compõem um determinado lugar/região e considerando esse lugar como uma fração do todo terrestre:

A Geografia proposta por Ratzel privilegiou o elemento humano e abriu várias frentes de estudo, valorizando questões referentes à história e ao espaço, como: a formação dos territórios, a difusão dos homens no globo (migrações, colonizações etc.), a distribuição dos povos e das raças na superfície terrestre, o isolamento e suas consequências, além de estudos monográficos das áreas habitadas. Tudo tendo em vista o objeto central que seria o estudo das influências que as condições naturais exercem sobre a evolução das sociedades. Em termos de método, a obra de Ratzel não realizou grandes avanços. Manteve a ideia da Geografia como ciência empírica, cujos procedimentos de análise seriam a observação e a descrição. Porém, propunha ir além da descrição, buscara síntese das influências na escala planetária, ou, em suas palavras, "ver o lugar como objeto em si, e como elemento de uma cadeia" (MORAES, 2002, p. 61).

A importância histórica de Friedrich Ratzel, tanto para a ciência geográfica quanto para outros ramos do saber científico, ainda não recebeu o reconhecimento necessário, pois muitas de suas ideias e teorias acabaram por ser estigmatizadas. Isso porque essas serviram de base para estudos reducionistas ${ }^{11}$ desenvolvidos não só pela Geografia, mas também por intelectuais de outras ciências, o que somente contribuiu para uma interpretação equivocada do pensamento geográfico ratzeliano.

\footnotetext{
${ }^{11}$ Nas palavras de Jörn Seemann (2017), a geógrafa americana Ellen Churchill Semple (1863-1932), aluna do Ratzel em Leipzig, contribuiu consideravelmente a essa visão distorcida e equivocada do geógrafo alemão ao extrair ideias do primeiro volume da Anthropogeographie para a sua própria visão geográfica. As suas interpretações não reproduziram a essência do pensamento de Ratzel, mas serviam como referência exclusiva para muitos geógrafos anglo-saxônicos que não se dispuseram a folhear os originais alemães da obra ratzeliana (p. 8).
} 
Ressalta-se que a contribuição teórica de Ratzel é indissociável da sua trajetória individual e do seu contexto de vida, de modo que seu trabalho expressa influências e contribuições diretas dos pensamentos dos seus mestres e interlocutores. Entre os principais influenciadores da obra de Ratzel, destacam-se os geógrafos Humboldt e Ritter, bem como as contribuições do pensamento de Chevalier de Lamarck (1744-1829), Kant e, especialmente, contribuições de Darwin. Seu primeiro contato com o trabalho de Darwin teria sido através do pensamento ecológico do prussiano Ernest Haeckel (1834-1919), seu professor em Jena. Foi durante e após sua passagem na América do Norte que Ratzel teria adaptado as ideias do naturalista inglês para sua compreensão analítica de humanidade. Isso porque, segundo Claval;

Vivamente interesado por la publicación del Origen de Las Especies, este sabio se había erigido en propagador de las ideas de Darwin em Alemania. Ratzel publicó en 1869 una obra en la que resumia lo esencial de la doctrina darwiniana, vista através de la enselianza y de los artículos de Haeckel (1981, p. 51).

É a partir dessas influências que o geógrafo alemão desenvolve seus conceitos básicos de geografia política, começando pela ideia do lebensraum (espaço vital), que se constitui em dos seus principais legados. Essas referências situam Ratzel dentro do positivismo ${ }^{12}$; de fato, sua obra é basicamente uma tentativa de dotar de base científica - teoria, leis, previsibilidade - o comportamento espacial das sociedades e dos corpos políticos.

No que se refere efetivamente ao debate das questões de natureza raciológica, Ratzel em seus principais trabalhos, Antropogeographie (1842) e Volkerkunde (1885), demonstra ser contrário à perspectiva tipológica de raças que fixavam grupos humanos em espécies distintas. Vale lembrar que nesse período

\footnotetext{
${ }^{12}$ De acordo com o geógrafo Horácio Capel (1981, p. 268-273), o positivismo é uma metodologia científica e também uma concepção filosófica que se difundiu primeiramente na Europa, em meados do século XIX. As ciências naturais foram tomadas como modelo, com as ideias de neutralidade e infalibilidade científica, pela crença no progresso.
} 
em que Ratzel concebeu seus escritos, já no final do século XIX, as teorias racialistas enfrentavam pesadas críticas e contestações. De modo que as ideias biologicistas, que até então fixavam as raças em espécies, foram gradualmente colocadas em xeque nesse período.

É nesse momento que começa a se tornar hegemônico na Europa o entendimento de que humanidade era uma única espécie, mesmo que internamente diferenciada em raças. Nas palavras do próprio geógrafo alemão, “nenhum povo e nenhuma raça são privados de características fundamentais da humanidade onde quer que se situem. Contudo, as mais profundas diferenças de raça derivam, em parte, do ambiente" (RATZEL 1990, p. 57). É nesse bojo que

[...] à primeira vista Ratzel parece definir raça como os aspectos morfológicos do corpo (cor da pele, textura do cabelo, estatura etc.), contudo, a todo momento essa categoria é colocada como sinônimo de povo. Ora raça é utilizada como referente para características somáticas, ora para se referir a aspectos que evidenciam coletividades sociais específicas e, em alguns casos, como ambas ao mesmo tempo. É nesses termos que o mesmo traz em seu vocabulário, por exemplo, "povos de cor escura" e "povos de cor clara" o que articula características físicas e grupais de coletividades humanas. Deve-se ressaltar, no entanto, que a ambiguidade entre povo e raça em Ratzel não é fortuita, estava ligada às concepções e usos de tais terminologias na época. Como evidencia a literatura sobre relações raciais no período, o termo raça era bastante polissêmico no fim do século XIX e podia ser utilizado tanto para identificar as características físicas de uma pessoa, quanto para identificar a população de uma nação. Ainda assim, deve-se salientar que Ratzel não estava preocupado em delimitar uma noção estrita de raça ou mesmo de povo - apesar de utilizar amplamente essas categorias. O que o interessava de fato era o grau e a qualidade da influência do meio na constituição das raças (ou dos povos), no que se refere principalmente a sua "fisiologia" e a "psicologia" (CIRQUEIRA, 2015, p. 70-71).

Nota-se o fato de que, apesar de se diferenciar dos principais tipologistas de sua época, o autor opera suas reflexões utilizando-se das mesmas noções 
básicas de "tipos gerais" definidos pelos teóricos tipologistas. É nesse contexto que o autor utiliza em seu vocabulário, por exemplo, a ideia de uma "raça branca ou caucasiana", "raça amarela ou asiática" e "raça negra ou africana" (Ibidem, p. 70).

Destaca-se que mesmo compreendendo que as diferenças no interior da humanidade eram condicionadas, precisamente, a partir do solo ou meio físico Ratzel apresentava um argumento muito característico do discurso imperialista europeu. Segundo Cirqueira (2015) em sua produção geográfica Ratzel deixa explícita sua crença na superioridade eurobranca a partir da inferiorização dos outros grupos étnico-culturais do planeta. De modo que, quando Ratzel cunha a categoria naturvölker ("povos naturais"), ele se refere subliminarmente a "africanos", "aborígines australianos", "malaios" e outros povos melanodérmicos. Enquanto a expressão de kulturvölker ("povos civilizados") é associada exclusivamente aos povos europeus brancos. Cirqueira (2015, p. 71) acrescenta ainda que

Os adjetivos "natural" (natur) e "civilizado" ou "de cultura" (kultur) se conformam como instâncias binários de alteridade cuja afirmação do civilizado se dá com a negação desse carácter nos "outros". Os europeus só podem ser civilizados em comparação com os povos naturais! Por mais que Ratzel afirme que essas denominações não possuam qualidade de hierarquização, é importante notar que, como um pressuposto óbvio da luta entre as espécies, essa ideia - nesse contexto - é imantada de poder e legitima ações de dominação, sobretudo dos "civilizados" sobre "naturais".

Outra importante escola que marcou a Geografia (Tradicional) Moderna foi a Escola Geográfica Francesa, que ganhou notabilidade entre o final do século XIX e o início do século XX. Seu maior expoente foi o geógrafo francês Paul Vidal de La Blache (1845-1918), que lecionou no liceu de Angers, na École Supérieure des Lettres et Sciences e foi nomeado (em outubro de 1872) professor do curso de História e Geografia da Faculdade de Letras de Nancy, onde, na verdade, ensinará somente Geografia. La Blache ajudou a estruturar a ciência geográfica na França 
a partir do seu livro Principes de la géographie humaine, publicada postumamente em 1922, por seu discípulo Emannuel de Martonne.

A Geografia Humana de Vidal de La Blache propunha um novo método à geografia, inserindo uma perspectiva histórica e funcional. As relações homemmeio eram encaradas nessa perspectiva com uma abordagem recíproca e harmônica. Segundo o geógrafo francês, do mesmo modo que as espécies animais e vegetais, o homem também recebia influências e se "adaptava" ao seu ambiente. Nesse contexto, importava sempre assinalar a influência do relevo, do clima, da posição continental ou insular; o homem era tido como um "fator geográfico" e a ideia de civilização se resumia à luta contra obstáculos físicos.

Nota-se que, diferentemente da obra dos geógrafos deterministas, na Geografia Lablachiana o homem não era apenas um elemento entre muitos outros. Na obra de Vidal, ele se faz mestre dos outros elementos, pois se adapta à natureza e a transforma em seu próprio benefício a partir das possibilidades que o meio oferece. Nesse contexto, o homem estaria inserido nessa complexa rede de relações, sendo ora sujeito passivo, ora ativo, pois, quando se depara com as possibilidades do meio, tem inteligência para aumentar os recursos e utilizálos de forma satisfatória. É por esse fato que, segundo Vidal, os estudos em geografia regional deveriam valorizar a idiossincrasia, o particular, aquilo que não se repete e que deveria ser descrito de forma minuciosa através das monografias, partindo da observação e descrição de uma região que se manifesta evidente na paisagem, pela integração harmônica entre seus aspectos naturais e históricos (FABRICÍO; VITTE, 2011).

Nesse sentido, "uma monografia regional deveria, na perspectiva lablachiana, conter uma análise detalhada do meio físico, das formas de ocupação, das atividades humanas e de como o homem se ajusta à natureza" (LENCIONI, 1999, p. 105).

Vale ressaltar que o geógrafo Ratzel com a sua Antropogeografia foi uma 
das principais referências intelectuais, para o estabelecimento da Geografia Humana de Vidal da La Blache e, apesar de algumas pequenas divergências ${ }^{13}$, os dois convergiam no tratamento dado à região e ao Estado, tanto na defesa do colonialismo quanto na própria visão geopolítica.

É fato conhecido que Vidal recorreu diretamente ao mestre alemão em seu período de formação, meses antes de assumir a cátedra de Geografia e História em Nancy (janeiro de 1873). Que ele se baseou notadamente em geógrafos alemães não é novidade; a literatura geográfica alemã era bem superior à francesa. A tomar pela Geografia, o círculo de Vidal de La Blache possuía contatos profundos com a geografia alemã. Este geógrafo estudara as obras de Ritter e assistira conferências de Richthofen, Peschel, Theobald Fischer e Ratzel (RIBEIRO 2014, p. 420).

Sendo assim, podemos assegurar que a geografia lablachiana, mesmo contestando alguns pressupostos positivistas, herdou muitos conceitos evolucionistas, vigentes no pensamento científico do século XIX, especialmente na obra de Ratzel. Esses conceitos podem ser identificados em quatro concepções distintas desenvolvidas pelo geógrafo francês: “organismo, meio, ação humana e gênero de vida" (GOMES, 1996, p. 198).

Nesse bojo, é seguro afirmar que o trato da temática racial também ocupou lugar privilegiado na Geografia de Paul Vidal de La Blache, tal como na obra dos seus predecessores. De modo que a abordagem dessas questões na Geografia francesa ocorreu com fortes indicativos eurocêntricos e imperialistas, como na produção geográfica de outros intelectuais europeus. Ao propor uma definição conceitual conclusiva sobre a categoria raça em sua obra, La Blache assinala que;

Nós entendemos como raças as divisões fundadas nos caracteres somáticos, que afectam quer a morfologia, quer a fisiologia do corpo humano. Atualmente, as raças físicas

\footnotetext{
${ }^{13}$ Vale ressaltar que foi o historiador francês Lucien Febvre (1878-1956) o responsável por atribuir o estereótipo de determinista à geografia ratzeliana e possibilismo (termo que Vidal nunca utilizou) à geografia lablacheana, criando uma suposta polarização entre os dois intelectuais.
} 
manifestam-se raramente na sua integridade; geograficamente, não se distinguem mais do que grupos mestiçados. É, todavia, certo que a cor da pele, os índices cefálico, nasal e órbito-nasal, a forma dos cabelos e a altura fornecem testemunhos persistentes de caracteres físicos que se diferenciaram, fixaram e transmitiram de idade em idade, persistindo mais ou menos puros apesar de todas as mestiçagens. Nenhuma experiência nos autoriza a pensar que o negro, o amarelo ou o branco possam, mesmo com o decorrer do tempo, perder os seus caracteres típicos pela simples razão de viverem num meio diferente do habitat de origem (LA BLACHE, 1954, p. 366).

Fica explícito que a concepção de raça de Vidal de La Blache é bastante complexa e relativista. O autor deixa evidências de que estava a par das discussões sobre o caráter falso das determinações raciais, inclusive muitos pesquisadores de sua época se contrapunham à sua utilização científica e política (CIRQUEIRA, 2015). Em sua obra Princípios de Geografia humana, que ficou inacabada em virtude do seu falecimento, o geógrafo francês reporta aos povos ditos "primitivos" sua dependência em relação ao meio. Por essa razão, a primeira parte da obra é dedicada à explicação da distribuição dos homens na superfície terrestre mediante a "evolução" dos povos.

Para Vidal, a distribuição dos homens no globo ocorreria por uma progressão descontínua, produzindo isolamentos. Segundo ele, partir da aglomeração de núcleos humanos ao longo do curso de rios ocorreu uma separação por obstáculos, como montanhas. Em sua obra, o autor considera que "é preciso conceber grandes espaços habitualmente vazios, vastas zonas de isolamento" (BLACHE, 1954, p. 365). Nesse isolamento, em sua relação com o meio, o homem teria supostamente engendrado seu modo de vida, levando à criação de técnicas capazes de transformar o ambiente. Compreendidos a partir de concepções evolucionistas, esses isolamentos, de acordo com Vidal, levaram à formação de raças que, em vários casos, não cessam de modificar-se.

As origens das principais diversidades de raças escapam- nos [...] Mas [...] muitos fatos advertem-nos de que a 
matéria humana conserva sua plasticidade e que, incessantemente modelada pelas influências do meio, é capaz de prestar-se a combinações e formas novas. O trabalho da formação de raças está sempre a fazer-se (LA BLACHE, 1954, p. 373).

Em alguns casos, segundo La Blache, a população ficaria estagnada em seus hábitos, assemelhando-se às sociedades animais, por serem presas, historicamente, à mesma forma de interação com o meio (LA BLACHE, 1954, p. 8084). O geógrafo ainda aponta que supostamente o meio europeu teria sido muito mais exigente. Por essa razão, segundo ele, a população que lá vive desenvolveu um povoamento original, capaz de uma evolução mais complexa.

Se tivermos apenas como horizonte de referência a obra geográfica de Ratzel no âmbito ao ao debate racial, vamos perceber que é um processo bem mais laboroso encontrar na Geografia de La Blache uma abordagem racialista explícita. Entretanto, ao se lançar um olhar mais atento sobre os textos do autor, notam-se traços de uma visão eurocêntrica por vezes marcada por uma biologia evolucionista racista. Na percepção de Cirqueira acerca da obra do geógrafo francês:

Sem dúvida, La Blache, conceitualmente, despe da noção de raça todo aspecto determinista e essencialista. Entretanto, do ponto de vista analítico, permanece a utilização da categoria para distinguir e hierarquizar "os homens" e "povos". Apesar dos avanços do autor, no que se refere à relativização e complexificação de categorias e análises, ainda percebemos em suas leituras uma "metodologia da comparação implícita. Podese aqui levantar as seguintes críticas, na forma como é utilizada a raça pelo autor: ainda que conteste as ideias rígidas de raça, ao enfatizar os processos de caldeamento e de constantes transformações, La Blache ainda opera com os "tipos gerais" (branco, negro e amarelo), pois, a resistência dos tipos é um dos factos que os progressos dos estudos antropológicos têm posto em foco. Há caracteres constantes a par de outros que podem variar. Um exemplo evidente é que, apesar de enxergar um crisol de raças e povos na Europa, sua interpretação dá a entender que essa diversidade está contida no tipo geral branco. Do mesmo modo, em alguns casos o autor sobrepõe 
esses tipos a categorias espaciais, como países, continentes e regiões. Encontramos, assim, expressões como "países negros" - ao se referir aos grupos humanos subsaarianos em África ou "os pretos de África" e os "Índios da América do Sul", "europeus brancos", "japoneses amarelos" etc. (2015, p. 93).

Basta uma análise mais depurada para detectar o fato de que na geografia lablachiana os europeus são apresentados quase sempre como referência civilizacional do mundo. Para Vidal, a civilização se restringia aos grupos humanos de raça branca localizados em território europeu. Segundo o geógrafo, os povos da Europa teriam uma tendência inerente ao aperfeiçoamento. Segundo ele, a Europa ocidental teria apresentado, num movimento histórico, um desenvolvimento quase contínuo, o que supostamente não ocorreu com as civilizações do continente africano e asiático, tampouco com habitantes das zonas de deserto e de estepes. Nas próprias palavras de La Blache, “Em toda parte da África que ainda não foi modificada pelas influências europeias ou árabes, não existem cidades no verdadeiro sentido da palavra"; (2012, p. 14-415).

Para Vidal, essas regiões estariam em um eterno estado de atraso civilizacional se comparado com a realidade dos povos europeus. Essa percepção fica explícita quando ele aponta que, diferentemente do continente africano e asiático, "A cidade é hoje, na América e na Austrália, o signo por excelência da apropriação europeia, o núcleo do Estado" (LA BLACHE, 2012a, p. 416). Ou seja, quanto mais próximo ou semelhante à Europa, mais avançado esse povo se torna em termos civilizacionais. É por isso, segundo ele, que os europeus deveriam propagar seu "progresso" e "evolução" para outros gêneros de vida (LA BLACHE 1954, p. 277-278).

Os ventos, as correntes, os rios e os animais têm seu papel na dispersão das espécies. Mas de todos os agentes que dessa forma criam o intercâmbio entre as diversas partes da Terra, que alteram o equilíbrio sempre provisório do mundo animado, nenhum, naturalmente, é comparável ao homem. O europeu moderno, sobretudo, é o artesão infatigável de uma obra que 
tende a uniformizar, se não o planeta, pelo menos cada uma das zonas do planeta (LA BLACHE, 2012 [1898], p. 409).

Ressalta-se que a Geografia de Vidal influenciou ativamente a expansão colonial francesa. Segundo Ribeiro (2009, p. 26), “[...] Vidal de La Blache atua em várias frentes: favorável às pretensões do Comitê da África Francesa, faz conferências sobre as colônias e sua revista é um espaço privilegiado de atuação em prol da expansão colonial [...]". "Toda obra de La Blache está imbuída de uma visão política a serviço do colonialismo francês" (MAMIGONIAN apud PEREIRA, 2012, p. 341).

De acordo com as palavras do próprio geógrafo: “Devemos nos congratular porque a tarefa da colonização que constitui a glória de nossa época, [...]" (LA BLACHE apud SANTOS, 1978, p. 15). Vale lembrar que a criação, no ano de 1892, da cadeira de "Geografia Colonial", na França, já colocava em evidência a inclinação imperialista da Geografia de Vidal de La Blache, bem como seu esforço na defesa e justificativa da obra colonial francesa.

\section{AS QUESTÕES RACIAIS NA GEOGRAFIA DO BRASIL - UM DIÁLOGO A PARTIR DAS} CONTRIBUIÇÕES DA OBRA DE DELGADO DE CARVALHO \& AROLDO DE AZEVEDO.

Conforme explicitamos anteriormente, a Geografia moderna originou-se no contexto de afirmação dos Estados Nacionais Europeus, atingindo seu apogeu nos países que buscavam na ciência a superação da fragmentação feudal e do seu processo tardio de unificação nacional, tal como foi na Alemanha. É nesse contexto que as teorias e conceitos de geografia se difundem com ampla eficácia ideológica na Europa e no mundo.

A Geografia brasileira é o reflexo da sistematização da ciência geográfica na Europa, porém com características particulares e específicas do nosso território. A Geografia no Brasil se institucionalizou na década de 1930, com a criação da Faculdade de Filosofia, Ciências e Letras da Universidade de São Paulo (USP) em 
1934, e com a criação da Universidade do Distrito Federal, atualmente Universidade Federal do Rio de Janeiro, em 1935. Segundo o geógrafo Manoel Correia de Andrade, a década de 1930 é tida como um marco para a Geografia no Brasil. O autor explica que:

[...] a evolução do pensamento geográfico no Brasil é analisado, quase sempre, a partir da década de 30 , quando o país em consequência de uma revolução que destruiu grande parte das estruturas da Primeira República (1889/1930), realizou mudanças sensíveis no seu sistema de ensino... (ANDRADE, 1994, p. 52).

É bem verdade que ainda na chamada República Velha também foram publicados livros de interesse geográfico, entretanto os trabalhos publicados durante esse período, no Império e na Primeira República, no Brasil, se resumiram em levantamentos estatísticos, estudos descritivos e a produção de alguns atlas produzidos pelos Institutos e Sociedades Geográficas. Ainda assim, vale ressaltar que o papel desempenhado pelo o Instituto Histórico e Geográfico Brasileiro e seus congêneres estaduais, o Conselho Nacional de Geografia e a Sociedade de Geografia do Rio de Janeiro, foram de extrema relevância no processo de institucionalização da ciência geográfica.

Ainda nos anos de 1930, foi criado, na cidade do Rio de Janeiro, o Instituto Brasileiro de Geografia e Estatística (IBGE), composto de três conselhos - o de Geografia, o de Cartografia e o de Estatística. O IBGE foi criado com o objetivo de desenvolver o conhecimento do território nacional através da racionalização de uma política de coleta de dados estatísticos que dariam suporte à administração pública. O IBGE, mesmo tendo contribuído para a formação de muitos professores para as universidades, foi a primeira instituição no Brasil a receber geógrafos voltados exclusivamente para a pesquisa.

A escola da Geografia moderna de tradição francesa exerceu grande influência na formação do conhecimento acadêmico de Geografia que se 
desenvolveu no Brasil. Muitos geógrafos brasileiros se filiaram aos preceitos e orientações epistêmicas de Vidal de La Blache e da chamada "Escola Possibilista Francesa".

No Brasil, a chamada escola possibilista, estimulou a fragmentação da realidade (coisa não pregada por Vidal), o isolamento da Geografia entre as ciências sociais e desestimulou a procura de causas na apreensão do todo. Produziu uma indefinição da Geografia ao não situá-la nem como ciência da natureza, nem como ciência social, colocandoa como uma "ciência de charneira" e reforçando a ideia de "ciência síntese", que se comportou como uma simples aglutinadora dos resultados de outras ciências (DE CAMPOS 2015, p. 5).

Um dos geógrafos mais influenciados pela Geografia lablachiana no Brasil foi o geógrafo Carlos Miguel Delgado de Carvalho (1884-1980).

[...] a influência no Brasil de Vidal de La Blache começou claramente com Delgado de Carvalho. Em Geografia Humana utilizou, embora poucas vezes, o termo "ciência geográfica", mas com uma concepção presa à Escola Regional Francesa: dual, compartimentada e indefinida quanto ao seu objeto (Ibidem, p. $6)$.

Mais conhecido apenas como Delgado de Carvalho, filho de um diplomata brasileiro com uma francesa, Delgado nasceu na França no final do século XIX e estudou direito na Universidade de Lausanne e ciências políticas em Paris. Depois, realizou estudos em diplomacia e teve uma breve passagem pela London School of Economics. Apesar de não ser geógrafo de formação, Delgado de Carvalho é considerado um dos founding fathers da Geografia brasileira em função de seu trabalho apresentar um escopo metodológico geográfico, bem como em virtude de sua preocupação com a profissionalização e institucionalização do saber geográfico no Brasil. Sobre a importância que esse geógrafo ocupou na Geografia brasileira, Andrade faz a seguinte consideração: 
Delgado de Carvalho é considerado o iniciador dos estudos de geografia científica no Brasil e o nosso primeiro geógrafo. Ele se antecipou ao que ia ocorrer após a Revolução de 30 e, condicionado por ela, com o pensamento geográfico no Brasil, possibilitou a institucionalização da geografia como ciência a ser estudada em nível superior e a ser aplicada à problemática nacional (1994, p. 69).

Vale ressaltar também que Delgado de Carvalho foi um dos geógrafos pioneiros no trabalho do ensino de Geografia na educação básica no Brasil. Durante as três primeiras décadas do século XX, há uma significativa produção de material didático desse autor voltada aos professores e estudantes do ensino secundário. Tendo em vista o seu trabalho como escritor e a sua influência e atuação no Colégio Pedro II, podemos assegurar que a obra de Delgado de Carvalho e, consequentemente, sua perspectiva de Geografia determinaram em maior ou menor escala a Geografia que se ensinou e que ainda se ensina no Brasil.

Seguindo a tradição francesa, de onde é originário, o geógrafo Delgado de Carvalho também se apropriou da categoria de raça em seus trabalhos. Segundo Cirqueira (2015), existem dois aspectos que se destacam na obra de Delgado de Carvalho em relação à perspectiva racial. Os aspectos podem ser notados na forma como o geógrafo aborda as diferenças humanas em suas reflexões: primeiramente, o autor coaduna com a perspectiva da existência de "typos sociais humanos" mais adequados para cada meio específico ou para as diversas "exigências naturais". Em seus próprios termos, "cada região [natual] fórma[ria] um typo social humano, amoldado as suas exigências naturaes" (CARVALHO, 1930, p. 242).

Outra questão que atravessa as proposições do geógrafo acerca da formação dos "typos humanos" é a importância da mestiçagem para a formação brasileira.

Assim, nesse contexto, as discussões e proposições de Delgado de Carvalho são forjadas essencialmente pelos debates que 
vinham ocorrendo em torno desse assunto na realidade brasileira. Em meio a uma visão otimista e pessimista da mestiçagem entre nós, o autor se coloca do lado da primeira. Delgado de Carvalho cria que a mestiçagem não era degenerante, mas sim, um processo passageiro, cujo fim seria marcado pela prosperidade - na medida em que resultaria uma sociedade mais branca e civilizada. Algo que, no entanto, é novo acerca dessa discussão é o encadeamento que o geógrafo realiza entre a dimensão regional e o caldeamento racial [...] (CIRQUEIRA, 2015, p. 183).

Delgado de Carvalho sustenta, em sua obra, que o processo de mestiçagem não cria tipos novos de grupos raciais, pois os indivíduos gerados em processos de mistura racial tendem a regressar ao "typo primitivo". Os mestiços, assim,

[...] não são, pois, uma raça nova; são idênticos entre si e nas suas gerações sucessivas não guardam fixidez no typo, sendo sempre a tendência voltar a um dos typos primitivos, ao mais perfeito physica ou intellectualmente, sendo frequente ás vezes a tendência a sobrepujar esses typos (CARVALHO, 1923, p. 124).

Para Cirqueira (2015), Delgado de Carvalho caminhou na contramão dos intelectuais da sua geração, à medida que destituiu da mestiçagem o fator supostamente degenerante que era propalado pelos intelectuais europeus do seu tempo. A estratégia do autor, de acordo com Cirqueira (2015), "é ressaltar que a mestiçagem não é um processo rígido que gera sujeitos perenemente degenerados - como a ciência europeia pregava, mas que, contudo, era um processo passageiro que tendia à estabilização, por regressar, inevitavelmente, ao 'typo primitivo"'. Indo além, Delgado de Carvalho (p. 185) ainda sugere que, "em muitos casos, o processo de miscigenação poderia gerar sujeitos que superariam os 'typos primitivos"'.

Outro importante intelectual herdeiro do legado da Geografia moderna francesa e que atuou ativamente no processo do fortalecimento da ciência geográfica no Brasil nas primeiras décadas do século XX foi o geógrafo paulista Aroldo Edgard de Azevedo, mais conhecido como Aroldo de Azevedo (1910-1974). 
O geógrafo era formado em Direito na Universidade Federal do Rio de Janeiro (UFRJ), porém nunca exerceu a profissão. Ele também ingressou no ano de 1936, como estudante, no Departamento de Geografia e História da Faculdade de Filosofia, Ciências e Letras da USP e licenciou-se no ano 1939. Foi convidado a lecionar na mesma faculdade, logo após sua formatura. Azevedo trabalhou com as atividades do magistério na formação de professores para a disciplina de Geografia, até sua aposentadoria em 1967. Contudo, foi no campo da publicação de livro didático que o professor Aroldo mais se destacou. "Seus livros foram, na época, os preferidos do magistério nacional, sendo adotados na maioria das escolas [...] ele influenciou na formação de diversas turmas de professores e de alunos dos antigos ginasial e colegial, nas diversas regiões brasileiras" (CAMPOS, , 2015, p. 9). Azevedo publicou mais de 120 livros e artigos, intensificando sua produção principalmente entre os anos de 1940 a 1960.

Fortemente influenciado pela Geografia francesa, boa parte da produção de Azevedo possuía caráter empírico e obedecia à seguinte frequência: descrição e interpretação da paisagem; análises da relação entre o homem e meio; estudo da economia e conclusão.

[...] os geógrafos brasileiros, devidamente orientados pelos mestres franceses junto aos cursos de geografia criados no Brasil a partir de 34 , já contavam com todo um receituário metodológico para desenvolver as tarefas necessárias a um conhecimento empírico mais amplo e em moldes mais sistemáticos do território nacional. E é claro que esse contexto se dava em função dos interesses e das necessidades das classes dominantes que se encontrava.m, na época, absorvidas no processo de levantamento das potencialidades brasileiras e da consolidação do poder político do Estado sobre o espaço geográfico nacional. Portanto, combinou-se a disposição dos recursos metodológicos com as necessidades práticas, resultando, assim, no aperfeiçoamento do ensino, na divulgação dos métodos e na execução dos trabalhos empíricos. É, pois, de todo esse contexto [...] que surgiu a obra de Aroldo de Azevedo e a produção geográfica dos membros de sua geração acadêmica, todos empenhados num amplo trabalho de 
reconhecimento dos fatos da paisagem geográfica brasileira (SANTOS, 1984, p. 60).

Tal como na obra de seus mestres, a obra de Azevedo também apresenta como característica marcante uma forte orientação raciológica. Segundo Ferrancini (2013), no capítulo XII intitulado "Raças e povos da terra" do livro didático de título Geografia Geral, Geografia Astronômica, Geografia Física e Geografia Humana, editado no ano de 1936, pela Companhia Nacional, São Paulo, o geógrafo Aroldo inicia o capítulo propondo a divisão dos grupos humanos em “cor da pele, forma lodo crânio, qualidade do cabelo, forma do nariz, do queixo e classificações de raças" (AZEVEDO, 1936, p. 187 apud FERRANCINI). Não existe no livro uma apresentação do continente africano e sim diretamente a descrição da população.

Vejamos a figura a seguir, extraída do livro de Aroldo de Azevedo.

Figura 1 - Tipos de crânios

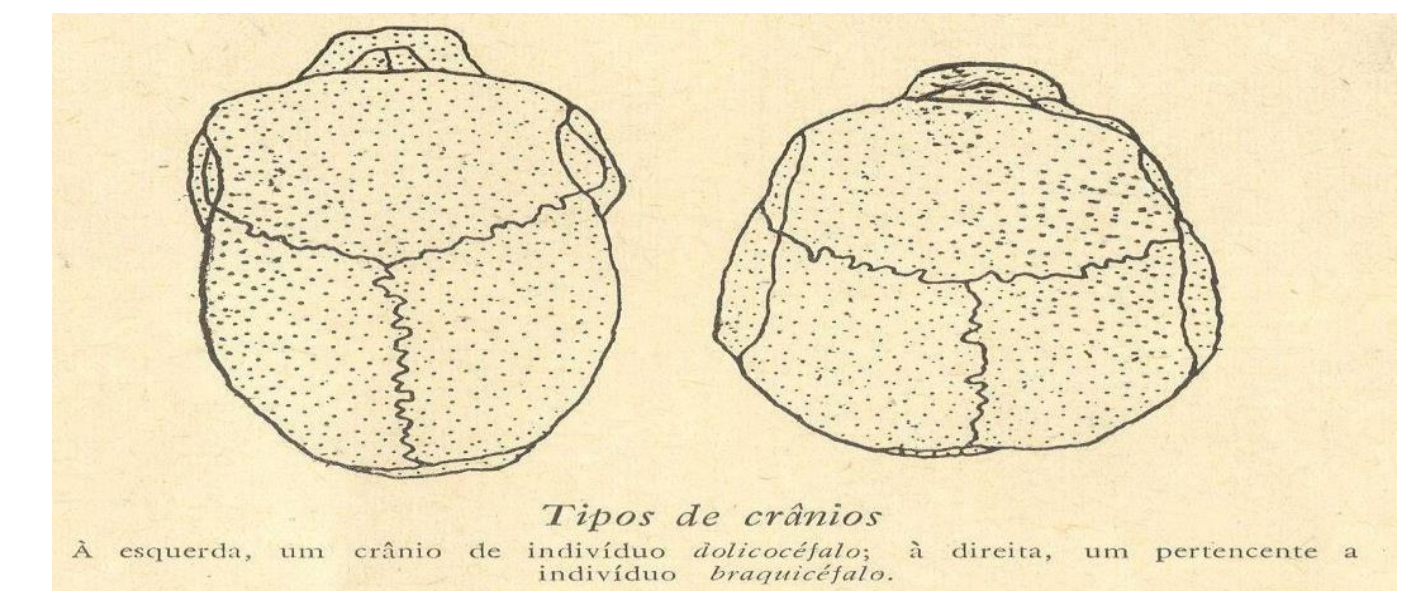

Fonte: Geografia Geral, Geografia Astronômica, Geografia Física e Geografia Humana, 1936. Obtido a partir de Ferrancini (2012).

A partir da imagem em destaque, fica explícito que, para Azevedo, é aceitável classificar os grupos humanos em ordem taxonômica a partir dos atributos do fenótipo. As raças, para o geógrafo paulista, podem ser definidas em função de um conjunto de característica associados à cor da pele (negros, brancos e amarelos), bem como à textura do cabelo (lisos, anelados e crespos), 
índice nasal ou até mesmo tamanhos da caixa do crânio entre dolicocéfalos ou braquicéfalos, recriando variáveis que, inclusive, já passavam por duras críticas nas primeiras décadas do século XX.

Em um ato de cientificismo, muitos desses geógrafos e geógrafas expressam o uso de "critérios de classificação" e de expressões cunhadas pelos cientistas racistas europeus e brasileiros da antropometria e craniometria do período supracitado. Falam em "grau de civilização" e utilizam para classificar grupos aspectos como "côr da pele", "cabelo", "Estatura", "forma da cabeça", "índice cefálico", "ângulo facial", "índice nasal", "capacidade craniana" etc. Esse vocabulário pode ser visto, por exemplo, na obra Geografia Humana de Delgado de Carvalho e Terezinha de Castro (1963), ao tratarem dos "grupos humanos" num primeiro momento e das "etnias brasileiras" posteriormente (CIRQUEIRA, 2015, p. 202).

Aroldo de Azevedo mescla dados estatísticos e leituras antropológicas sobre a ideia de raças e etnias existentes no conjunto da população brasileira. $\mathrm{O}$ geógrafo se utiliza de múltiplos recursos em sua obra Geografia Gera/de 1952 na tentativa de sustentar seu discurso sobre as características que distinguem os grupos humanos em raças distintas.

Figura 2 - Os grupos humanos.
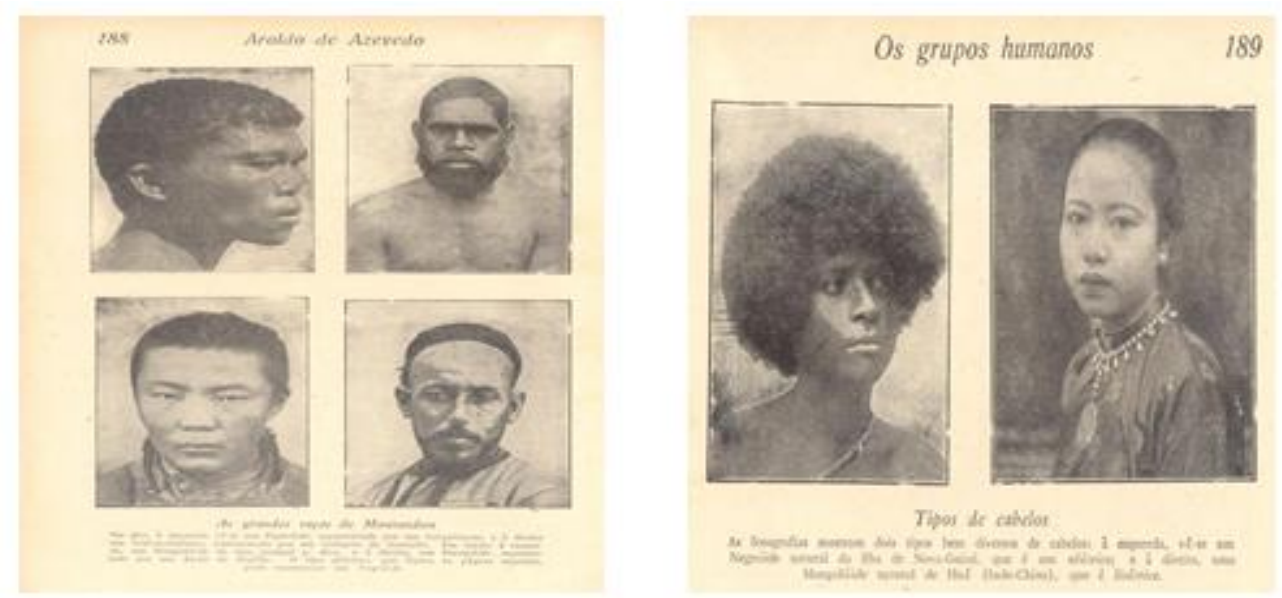

Fonte: Geografia Geral, 1952 (Obtido a partir de Ferrancini/2012)

De forma mais objetiva, sobre a categoria raça, o autor sustentava que 
A cor da pele, constitui o traço mais sensível. Por isso mesmo de longa data distinguiram-se três raças: a branca, a amarela, e a negra. Mas hoje todos estão de acordo em que esta distinção é insuficiente, porque a pele humana apresenta elevado número de matizes (AZEVEDO 1952, p. 187).

Apesar de não defender de forma ampla e declarada a hierarquia entre os diferentes grupos raciais, tendo em vista que "Nos dias atuais [...] não parece razoável admitir-se que exista a superioridade de uma raça sobre outra" (AZEVEDO 1952, p. 163), ainda assim Azevedo não oculta sua inclinação para crença na superioridade dos europeus em relação aos outros grupos raciais, sobretudo quando reproduz os estereótipos raciais de sua época. Um reflexo dessa prática fica evidente quando o geógrafo sustenta que “[o mulato] não possui grande disposição para os trabalhos pesados, nem muito inclinação para o comércio ou a indústria" ou de que "[os caboclos] podem tornar-se traiçoeiros e vingativos, por vezes fanáticos em matéria religiosa" (AZEVEDO, 1975[1969], p. 122-123). Outro fato que exemplifica esse posicionamento contraditório de Azevedo fica latente quando ele retoma a proposta de divisão conforme os graus de civilização - selvagens ou primitivos, semicivilizados ou bárbaros e civilizados. Sobre essa questão, o geógrafo afirma que

[...] a cultura alcança suas altas manifestações. Procuram fortalecer e honrar a instituição da família. Adotam as religiões mais puras e perfeitas, preocupando-se em difundi-las. [...] Todavia, em muitas regiões do Mundo e mesmo no interior de nossas fronteiras, milhões de homens ainda desconhecem, parcial ou totalmente, as mais elevadas manifestações do espírito humano. Mongóis e árabes da Ásia, esquimós e ameríndios, povos primitivos da África e da Oceania estão em tal caso. Cumpre levar-lhes nossa civilização e nossa cultura (AZEVEDO, 1969a, p. 146).

Em outra circunstância, Azevedo assinala de forma ainda mais explícita suas convicções. O professor assevera que 
Entre os povos selvagens, as atividades culturais apresentam suas formas mais simples e rudimentares; muitas delas chegam mesmo a não existir. Daí o nenhum papel que representam no progresso humano. Neste caso estão todas as populações indígenas da América, os negros da África, alguns povos da Ásia (vedas, semang, negritos etc.) e os indígenas da Austrália e certas ilhas da Oceânia (papauas melanésios) (AZEVEDO, 1952, p. 185).

Por fim, nota-se que Azevedo manteve a visão etnocêntrica europeia característica marcante também na obra dos seus contemporâneos.

\section{CONSIDERAÇÕES FINAIS}

A partir dos aspectos observados no texto e tendo em vista a processo de construção e maturação da matriz teórica da Geografia ao longo do processo histórico desde a antiguidade clássica até sua institucionalização como ciência, podemos observar que a narrativa racial, e as questões relacionadas a essa temática sempre tiveram uma tratativa especial entre os muitos temas de interesse e pesquisa dos então chamados geógrafos.

A busca pela diversidade étnica e cultural sempre foram constantes dentro da Geografia, ainda que dentro de um víeis deturpado, e impregnado pela hierarquia racial desenvolvida precocemente pelos gregos e que foi posteriormente potencializada pelas disputas imperialistas que marcaram o final do século XIX e os primeiros anos do século XX.

Com esse trabalho estamos definitivamente situando o debate sobre raça no escopo teórico da Geografia, tendo em vista que o nosso texto aponta aquilo que já sinalizávamos, que a raça é um construto social ancorado em leituras de espaço e, portanto, ela também se constitui como um dos temas possíveis de serem contemplados pela ciência geográfica.

\section{REFERÊNCIAS BIBLIOGRÁFICAS}


ALVES, Vicente Eudes Lemos. A obra de Humboldt e sua provável influência sobre a antropologia de Franz Boas. GEOUSP: Espaço e Tempo (Online), n. 18, p. 67-79, 2005.

ARISTÓTELES. A política. Tradução de Roberto Leal Ferreira. São Paulo: Martins Fontes, 2002.

. Filósofo macedônio. Fisionomia, 6. Citado por Cheikh A. Diop, Origem negra do Egito. In: História Geral da África. Brasília, UNESCO, 2010. v. 2.

CIRQUEIRA, Diogo. Marçal. A questão negra na trajetória teórica do geógrafo Milton Santos. Anais XVI Encontro Nacional dos geógrafos, ENG, 2010.

. CORRÊA, Gabriel Siqueira. Questão étnico-racial na geografia brasileira: um debate introdutório sobre a produção acadêmica nas pós-graduações. Revista da ANPEGE, v. 10, n. 13, p. 29-58, 2012.

. Inscrições da racialidade no pensamento geográfico (1880-1930). Niterói, 2015. Tese (Doutorado em Geografia) - Programa de Pós-Graduação em Geografia, Universidade Federal Fluminense, 2015.

GUIMARÃES, Antônio Sérgio Alfredo. Racismo e Antiracismo no Brasil. São Paulo: Fundação de Apoio à Universidade de São Paulo; Ed. 34, 2005.

HASENBALG, Carlos. Discriminação e Desigualdades Raciais no Brasil. Rio de Janeiro, Graal, 1979.

LA BLACHE, Paul Vidal de. Princípios de Geografia Humana. 2. ed. rev. Lisboa: Edições Cosmos, 1954.

As características próprias da Geografia. In: CHRISTOFOLETTI, A. (Org.). Perspectivas da geografia. São Paulo: Difel, 1982. p. 37-47.

A Geografia Política: a propósito dos escritos do Sr. Friedrich Ratzel. In: HAESBAERT, Rogério et al. (Orgs.). Vidal, Vidais: textos de Geografia Humana, Regional e Política. Rio de Janeiro: Bertrand Brasil, 2012a. p. 401-420.

Aula Inaugural do Curso de Geografia. In: HAESBAERT, Rogério et al. (Orgs.). Vidal, Vidais: textos de Geografia Humana, Regional e Política. Rio de Janeiro: Bertrand Brasil, 2012b. p. 67-83.

MALACHIAS, Antonio Carlos. Geografia e relações raciais: desigualdades socioespaciais em preto e branco. 2006. Tese (Doutorado em XXX) - Universidade de São Paulo, São Paulo, 2006. 
MARCELINO, Jonathan da Silva. A força (dos) do Lugar: das lutas comunitárias ao comitê comunitário. A trajetória de R-existência do bairro Cidade de Deus na urbe Carioca. Dissertação (Mestrado) - Universidade de São Paulo. São Paulo, 2013.

Geografia, Movimento Negro e Relações Étnico-raciais: Um diálogo necessário. Tese (Doutorado) Universidade de São Paulo. São Paulo, 2019.

MORAES, Antônio Carlos Robert. Território e História no Brasil. São Paulo: Hucitec, 2002.

. Geografia: pequena história crítica. 20. ed. São Paulo: Hucitec, 1987.

A Gênese da Geografia Moderna. 2. ed. São Paulo: Hucitec, 2002.

. Geografia: pequena história crítica. 19. ed. São Paulo: Annablume, 2003.

MOREIRA, Ruy. A Geografia serve para desvendar máscaras sociais. In:

(Org.). Geografia: teoria e crítica - o saber posto em questão. Petrópolis: Vozes, 1982.

MUNANGA, Kabengele. Uma abordagem Conceitual das Noções de Raça, Racismo, Identidade e Etnia. Palestra proferida no $3^{\circ}$ Seminário Nacional Relações Raciais e Educação. PENESB-RJ, 05 nov. 2003. COSTA, D. M.; OSÓRIO, A. B.; SILVA, A. de O. Gênero e Raça no Orçamento Municipal: um guia para fazer a diferença, v. 1, p. 27, 2003.

RATTS, Alex Prudêncio. Corporeidade e diferença na Geografia Escolar e na Geografia da Escola: uma abordagem interseccional de raça, etnia, gênero e sexualidade no espaço educacional. Terra Livre, v. 1, n. 46, p. 114-141, 2018.

et al. Representações da África e da população negra nos livros didáticos de geografia. Revista da Casa da Geografia de Sobral, v. 8, n. 1, pág. 415, 2006.

WEDDERBURN, Carlos Moore. O racismo através da história: Da antiguidade à modernidade. São Paulo: Editora UNESP, 2007.

Submetido em: 11 de abril de 2021.

Aprovado em: 15 de outubro de 2021.

Publicado em: 23 de dezembro de 2021. 